\title{
U.V. spectra parameters to investigate the influences of intensifications of soybean with sorghum and maize on the physical properties of soybean seed oils
}

\author{
By N.S. Elsark (1), L.F. Rizk (2) and H.R. Doss (2) \\ 1. National Research Centre, Physics Department, Dokki Cairo. \\ 2. Agricultural Research Centre, Food Technology Research Institute, Giza. Egypt.
}

\section{RESUMEN}

Parámetros de espectros U.V. para investigar las influencias de intensificaciones de cultivos de soja con sorgo y maíz sobre las propiedades físicas de aceites de soja.

Se usaron medidas de espectros U.V. como una herramienta para investigar las influencias de intensificaciones o intercultivos sobre las propiedades físicas de los constituyentes de granos o semillas producidos.

En este trabajo el autor usó medidas de espectros U.V. para deducir los efectos de intensificaciones de variedades de soja Clark y Crowmord con variedades de sorgo y maíz sobre las propiedades físicas de los aceites de soja. Los resultados de este trabajo revelaron que los valores de espectros U.V. más elevados a $270 \mathrm{~nm}$, fueron 2'5 para los aceites de variedades de semilla de soja Crowmord intensificado con la variedad sorgo Giza 15 (2 filas soja: 4 filas sorgo) y las variedades de maíz Giza 2 (2:2 y 2:4), Hz 215 (2:4) y Hz 310 (2:2).

La intensificación de variedades de soja Clark y Crowmord con sorgo y maíz es efectiva, ya que las propiedades físicas de sus aceites mejoraron por aumento de los niveles de compuestos cromóforos y carotenoides.

PALABRAS-CLAVE: Aceite de soja - Intercultivo - Maíz - Propiedades físicas - Soja - Sorgo.

\section{SUMMARY}

U.V. spectra parameters to investigate the influences of intensifications of soybean with sorghum and maize on the physical properties of soybean seed oils.

Using U.V. spectra measurements as a tool to investigate the influences of intensifications or intercroping of crops on the physical properties of the constituents of the yielded grains or seeds.

In this paper the authors used U.V. spectra measurement to deduce the effects of intensifications of Clark and Crowmord soybean varieties on some sorghum and maize varieties on the physical properties of the oils of the soybean seed varieties. Results of this work revealed that the highest U.V. spectra measurements at bands $270 \mathrm{~nm}$, were 2.5 for the oils of Crowmord soybean seed variety intensificated on Giza 15 sorghum variety intensity 2:4 (2 rows soybean: 4 rows sorghum) and Giza 2, $\mathrm{Hz} 215$ and $\mathrm{Hz} 310$ maize varieties, intensity $2: 2,2: 4,2: 4$ and $2: 2$ respectively in the regions of spectra differences.

The intensification of Clark and Crowmord soybean varieties on sorghum and maize is effective as the physical properties of their oils improved by increasing the cromophor and carotenoids compound levels.

KEY-WORDS: Intercroping - Maize - Physical properties - Sorghum Soybean - Soybean oil.

\section{INTRODUCTION}

In Egypt the cultivation area is very limited. For this reason intensification of crops is widely used to increase the yield per feddan (acre). Intensification of soybean with maize or sorghum increases the feddans (acre) production by about $150 \%$ in comparison with the cultivation the separate crop.

Fats and oils have always an essential role as source of energy for mankind.

Chemically most oils are quite alike to make the detection of one oil, so no reliable test is stated in literature to detect these foreign oils or to differentiate between these oils and their origin.

Physical and chemical properties of oil play an important role in the variation between these oils for detection of their origin.

Williams (1950), reported that one would expect a wide variation in the data concerning the physical and chemical properties of lipids.

Grau and Mirna (1958), found that the absorption of lard at $268 \mathrm{~nm}$ increased in 26 days at $37^{\circ} \mathrm{C}$ from below 0.15 to over 1.0.

Much work had been done by Green et al. (1955); Davidek and Blattno (1962); Morris and Haenni (1962); Wilson et al. (1962), on IR spectrophotometry and other chemical technique investigations on oils.

In 1991, Elsakr and Fahmy measured the U.V. and I.R. spectra of fats and oils where their parameters had the U.V. maxima bands for oils at 272 and $260 \mathrm{~nm}$.

Gillam and Stern (1957) \& Selverstein and Bassler (1967), mentioned that the cromophor groups responsible for absorption at 265-300 $\mathrm{nm}$ regions were carbonyl groups of triglycerides esters, whereas the absorption at 400-500 $\mathrm{nm}$ regions was due to carotenoid compounds as described by Islers et al. (1956) \& Burkhardt (1968).

The object of this study was to evaluate the optical absorption by spectraparameters of some oils of soybean seeds produced from the production of cultivation of soybean intensificated on some sorghum and maize varieties. 


\section{MATERIALS AND METHODS}

Thirty soybean samples were obtained from Crops Intensification Department, Agricultural Research Centre, Giza, Egypt

The samples comprised two soybean varieties that were intensificated on sorghum and maize. These two varieties were similar Clark and Crowmord. Seven samples of both Clark and Crowmord soybean varieties were collected from the yield of soybean cultivated intensifically on some sorghum varieties and 9 samples of both Clark and Crowmord soybean varieties were purchased from the yield of soybean sowed intensifically on some maize varieties.

The sorghum varieties used for intensification of soybeans were Giza 15, H 1007 and Dorado and the maize varieties were Giza 2, $\mathrm{Hz} 204, \mathrm{~Hz} 215$ and $\mathrm{Hz} 310$.

Each variety of both sorghum and maize were planted in rows with ratios of 2 rows soybean: 2 rows sorghum or maize and 2 rows soybeans: 4 rows sorghum or maize.

The collected soybean seed samples were milled to pass 20 mesh. The ground samples were kept in tight containers in refrigerators at $3{ }^{\circ} \mathrm{C}$ for oil extraction [ether extract] as outlined by A.O.A.C. (1980).

Visible and ultraviolet absorption spectra were carried out for the soybean extracted oils from samples that were dried in a dry hexane and absorption were measured between $200-700 \mathrm{~nm}$ in a quartz cell with $1 \mathrm{~cm}$ path length against a solvent blank in a matched cell using Shimadzu double beam U.V. visible recording spectrophotometer Model U.V. 240 graphicord as prescribed by Vogel (1978).

\section{RESULTS AND DISCUSSION}

Table I presents that Clark soybean variety intensificated on Giza 15; 2:2 [2 rows soybean: 2 rows sorghum] sorghum variety which had the largest quantity of oils while the intensificated on Dorado 2:4 had the least. Also the crowmord soybean variety intensificated on $\mathrm{H} 1007,2: 4$ sorghum variety gave the highest levels of oils, but the intensificated on Giza 15, 2:4 gave the lowest.

Table I

Oil contents of Clark and Crowmord soybean seed varieties intensificated on sorghum varieties

\begin{tabular}{lccccc}
\hline & \multicolumn{2}{c}{ Clark } & & \multicolumn{2}{c}{ Crowmord } \\
\cline { 2 - 3 } \cline { 5 - 6 } Sorghum & $\begin{array}{c}\text { Moisture } \\
\mathrm{g} / 100 \mathrm{~g} \\
\text { Fresh Wt }\end{array}$ & $\begin{array}{c}\text { Fat } \\
\mathrm{g} / 100 \mathrm{~g} \\
\text { Dry Wt }\end{array}$ & & $\begin{array}{c}\text { Moisture } \\
\mathrm{g} / 100 \mathrm{~g} \\
\text { Fresh Wt }\end{array}$ & $\begin{array}{c}\text { Fat } \\
\mathrm{g} / 100 \mathrm{~g} \\
\text { Dry Wt }\end{array}$ \\
\hline Control & 7.00 & 21.87 & & 8.68 & 21.23 \\
Giza 15 2:2 & 7.79 & 21.87 & & 7.78 & 20.37 \\
Giza 15 2:4 & 7.69 & 20.40 & & 7.81 & 20.13 \\
H 1007 2:2 & 7.87 & 21.51 & & 8.10 & 21.71 \\
H 1007 2:4 & 7.50 & 21.66 & & 7.18 & 21.77 \\
Dorado 2:2 & 7.61 & 20.81 & & 8.17 & 21.67 \\
Dorado 2:4 & 8.16 & 20.22 & & 8.71 & 21.28 \\
\hline
\end{tabular}

In table II the data clarifies that the Clark soybean variety intensificated on $\mathrm{Hz} 215$ 2:4 [2 rows soybean: 4 rows maize] achieved highest oil values and the same soybean variety intensificated on $\mathrm{Hz} 204$ 2:4 gave lower values. Also this table shows that the Crowmord soybean variety intensificated on Giza, 2, 2:2 and $\mathrm{Hz}$ 204, 2:2 were the containers of the higher and lower oils.

Table II

Oil contents of Clark and Crowmord soybean seed varieties intensificated on maize varieties

\begin{tabular}{lccccc}
\hline & \multicolumn{2}{c}{ Clark } & & \multicolumn{2}{c}{ Crowmord } \\
\cline { 2 - 3 } \cline { 5 - 6 } Maize & $\begin{array}{c}\text { Moisture } \\
\text { g/100 } \mathrm{g} \\
\text { Fresh Wt }\end{array}$ & $\begin{array}{c}\text { Fat } \\
\text { g/100 g } \\
\text { Dry Wt }\end{array}$ & & $\begin{array}{c}\text { Moisture } \\
\mathrm{g} / 100 \mathrm{~g} \\
\text { Fresh Wt }\end{array}$ & $\begin{array}{c}\text { Fat } \\
\mathrm{g} / 100 \mathrm{~g} \\
\text { Dry Wt }\end{array}$ \\
\hline Control & 7.00 & 21.87 & & 8.68 & 21.23 \\
Giza 2 2:2 & 8.10 & 21.66 & & 7.84 & 21.89 \\
Giza 2 2:4 & 7.57 & 22.05 & & 8.45 & 21.39 \\
Hz 204 2:2 & 8.79 & 21.33 & & 8.58 & 20.19 \\
Hz 204 2:4 & 8.29 & 21.32 & & 8.38 & 21.51 \\
Hz 215 2:2 & 7.10 & 22.19 & & 8.17 & 21.33 \\
Hz 215 2:4 & 8.89 & 22.95 & & 7.90 & 21.83 \\
Hz 310 2:2 & 8.45 & 21.52 & & 7.72 & 21.51 \\
Hz 310 2:4 & 8.57 & 21.78 & & 7.58 & 21.23 \\
\hline
\end{tabular}

The oils of Clark and Crowmord soybean seeds that were cultivated intensifically on sorghum and maize were examined between $200-700 \mathrm{~nm}$. The absorption spectra showing the absorption throughout the above mentioned region is very useful to distinguish the effects of sorghum and maize varieties and the intensity of cultivation on the physical properties of the soybean seed oils yielded.

In the regions of the differences of the U.V. spectra measurements we may stress the interpretation of the results that outlined in the four tables number III, IV, V and $\mathrm{VI}$ shown below.

Table III

U.V. Spectra of the seed oils of Clark soybean variety intensificated on some sorghum varieties

\begin{tabular}{|c|c|c|c|c|c|c|c|}
\hline \multicolumn{2}{|c|}{ Spectrum Control } & \multicolumn{6}{|c|}{ Sorghum varieties of intensifications } \\
\hline $\mathrm{nm}$ & * & $\begin{array}{c}\text { Giza } 15 \\
2: 2^{\star *}\end{array}$ & $\begin{array}{c}\text { Giza } 15 \\
2: 4^{\star \star \star}\end{array}$ & $\begin{array}{c}\mathrm{H} 1007 \\
2: 2\end{array}$ & $\begin{array}{c}\mathrm{H} 1007 \\
2: 4\end{array}$ & $\begin{array}{c}\text { Dorado } \\
2: 2\end{array}$ & $\begin{array}{c}\text { Dorado } \\
2: 4\end{array}$ \\
\hline 475 & 0.08 & 0.12 & 0.12 & 0.12 & 0.12 & 0.20 & 0.06 \\
\hline 450 & 0.12 & 0.14 & 0.18 & 0.18 & 0.16 & 0.24 & 0.10 \\
\hline 420 & 0.12 & 0.12 & 0.16 & 0.12 & 0.12 & 0.20 & 0.08 \\
\hline 330 & 0.20 & 0.40 & 0.48 & 0.24 & 0.32 & 0.56 & 0.24 \\
\hline 270 & 1.70 & 2.08 & 2.24 & 1.60 & 2.00 & 2.35 & 1.68 \\
\hline 258 & 1.60 & 1.84 & 1.92 & 1.48 & 1.76 & 2.00 & \\
\hline 252 & 1.92 & & & & & & \\
\hline 230 & 2.16 & & & & & & \\
\hline
\end{tabular}

From the data shown in table III and figures 1 and 2 it is clear that the oils of Clark soybean seeds that intensificated on Dorado 2:2 (2 rows soybean:2 rows Dorado sorghum) and on Giza 15, 2:4 sorghum varieties have maxima bands at $270 \mathrm{~nm}$ given relative values 2.35 and 2.24 while the control Clark have the maxima bands at 230 with value of 
Table IV

U.V. Spectra of the seed oils of Clark soybean variety intensificated on some maize varieties

\begin{tabular}{|c|c|c|c|c|c|c|c|c|c|}
\hline \multirow{2}{*}{$\begin{array}{l}\text { Spectrum } \\
\mathrm{nm}\end{array}$} & \multirow[t]{2}{*}{ Control * } & \multicolumn{7}{|c|}{ Maize varieties of intensifications } & \multirow[b]{2}{*}{$\begin{array}{c}\mathrm{Hz} 310 \\
2: 4\end{array}$} \\
\hline & & $\begin{array}{l}\text { Giza } 2 \\
2: 2^{\star \star}\end{array}$ & $\begin{array}{l}\text { Giza } 2 \\
2: 4^{\star \star \star}\end{array}$ & $\begin{array}{c}\mathrm{Hz} 204 \\
2: 2\end{array}$ & $\begin{array}{c}\mathrm{Hz} 204 \\
2: 4\end{array}$ & $\begin{array}{c}H z 215 \\
2: 2\end{array}$ & $\begin{array}{c}\mathrm{Hz} 215 \\
2: 4\end{array}$ & $\begin{array}{c}\mathrm{Hz} 310 \\
2: 2\end{array}$ & \\
\hline . 475 & 0.18 & 0.16 & 0.14 & 0.24 & 0.13 & 0.18 & 0.40 & 0.16 & 0.18 \\
\hline 450 & 0.24 & 0.18 & 0.16 & 0.28 & 0.15 & 0.24 & 0.48 & 0.20 & 0.24 \\
\hline 420 & 0.24 & 0.16 & 0.15 & 0.25 & 0.13 & 0.17 & 0.40 & 0.18 & 0.16 \\
\hline 330 & 0.35 & 0.64 & 0.86 & 1.10 & & 0.64 & 0.26 & 0.96 & 0.85 \\
\hline 270 & 2.24 & 1.20 & 2.32 & 2.32 & 2.40 & 2.40 & 0.72 & 2.45 & 2.45 \\
\hline 258 & 2.00 & & & & & & & & \\
\hline 252 & 2.40 & & & & & & & & \\
\hline 245 & 1.92 & & & & & & & & \\
\hline 230 & 2.16 & & & & & & & & \\
\hline
\end{tabular}

* Clark or Crowmord soybean variety alone.

** 2 Rows soybeans: 2 Rows sorghum or maize.

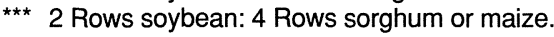

Table V

U.V. Spectra of the seed oils of the Crowmord variety intensificated on some sorghum varieties

\begin{tabular}{|c|c|c|c|c|c|c|c|}
\hline \multicolumn{2}{|c|}{ Spectrum Control } & \multicolumn{6}{|c|}{ Sorghum varieties of intensifications } \\
\hline $\mathrm{nm}$ & * & $\begin{array}{c}\text { Giza } 15 \\
2: 2^{* \star}\end{array}$ & $\begin{array}{c}\text { Giza } 15 \\
2: 4^{\star \star \star}\end{array}$ & $\begin{array}{c}\mathrm{H} 1007 \\
2: 2\end{array}$ & $\begin{array}{c}\mathrm{H} 1007 \\
2: 4\end{array}$ & $\begin{array}{c}\text { Dorado } \\
2: 2\end{array}$ & $\begin{array}{c}\text { Dorado } \\
2: 4\end{array}$ \\
\hline 475 & 0.08 & 0.10 & 0.20 & & 0.08 & 0.14 & \\
\hline 450 & 0.10 & 0.14 & 0.24 & & & 0.18 & \\
\hline 420 & 0.08 & 0.10 & 0.22 & & & 0.14 & 0.70 \\
\hline 320 & 0.30 & 0.24 & 0.56 & 0.16 & 0.32 & 0.85 & 2.40 \\
\hline 270 & 1.84 & 1.20 & 2.50 & 1.00 & 1.28 & 2.40 & 2.24 \\
\hline 255 & 1.84 & 1.20 & 2.24 & 1.00 & & & \\
\hline 250 & 2.50 & & & & & & \\
\hline 245 & 2.24 & & & & & & \\
\hline 240 & 3.32 & & & & & & \\
\hline 230 & 2.50 & & & & & & \\
\hline
\end{tabular}

* Clark or Crowmord soybean variety alone.

** 2 Rows soybeans: 2 Rows sorghum or maize.

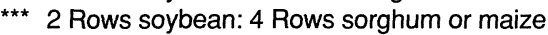

2.16. The minima bands for all oils of soybean intensificated of sorghum varieties were at $475 \mathrm{~nm}$ which gave values between 0.08 and 0.20 while for the control it was 0.08 .
From table IV and figures 3, 4 and 5 is clear that the oils of Clark soybean seeds cultivated intensifically on $\mathrm{Hz} 310$ 2:2 and 2:4 [2 rows soybean: 2 rows maize and 2 rows soybean:4 rows maize] maize variety have their maxima bands at $270 \mathrm{~nm}$ measuring 2.45 for both, while the control Clark that was cultivated separately has the maxima band at $252 \mathrm{~nm}$ measuring 2.40. The minima bands for all the oils of Clark soybean seeds cultivated intensifically on maize varieties were at $475 \mathrm{~nm}$ for Giza 2 and $\mathrm{Hz}$ 204, ranged between 0.13 and 0.24 , also at $420 \mathrm{~nm}$ for $\mathrm{Hz} 215$ 2:2 and $\mathrm{Hz} 310$ 2:4 gave 0.17 and 0.16 and at $330 \mathrm{~nm}$ for $\mathrm{Hz} 215$ 2:4 gave 0.26 while for the control Clark cultivated lonely the minima band was at $475 \mathrm{~nm}$ with a value of 0.18 .

From table $V$ and figures 6 and 7 it is clear that the oils of Crowmord soybean seeds variety that was cultivated intensifically on sorghum varieties had maxima bands at $270 \mathrm{~nm}$ giving values of 2.50 and 2.40 for Giza $152: 4$ and Dorado 2:2 [2 rows soybean:4 rows sorghum Giza 15 and 2 rows soybean:2 rows Dorado sorghum], while the maxima band for the control Crowmord soybean cultivated separately that was at 270 measured 1.84 . The minima bands for these oils of Crowmord soybean variety cultivated intensifically on sorghum varieties were at $475 \mathrm{~nm}$

Table VI

U.V. Spectra of the seed oils of Crowmord soybean variety intensificated on some maize varieties

\begin{tabular}{|c|c|c|c|c|c|c|c|c|c|}
\hline \multirow{2}{*}{$\begin{array}{l}\text { Spectrum } \\
\mathrm{nm}\end{array}$} & \multirow[t]{2}{*}{ Control * } & \multicolumn{7}{|c|}{ Maize varieties of intensifications } & \multirow[b]{2}{*}{$\begin{array}{c}\mathrm{Hz} 310 \\
2: 4\end{array}$} \\
\hline & & $\begin{array}{l}\text { Giza } 2 \\
2: 2^{* \star}\end{array}$ & $\begin{array}{l}\text { Giza } 2 \\
2: 4 * \star \star\end{array}$ & $\begin{array}{c}\mathrm{Hz} 204 \\
2: 2\end{array}$ & $\begin{array}{c}\mathrm{Hz} 204 \\
2: 4\end{array}$ & $\begin{array}{c}\mathrm{Hz} 215 \\
2: 2\end{array}$ & $\begin{array}{c}\mathrm{Hz} 215 \\
2: 4\end{array}$ & $\begin{array}{c}\mathrm{Hz} 310 \\
2: 2\end{array}$ & \\
\hline 475 & 0.18 & 0.10 & & 0.08 & 0.24 & 0.24 & 0.10 & & 0.18 \\
\hline 445 & 0.22 & 0.15 & & 0.12 & 0.25 & 0.25 & 0.14 & & 0.22 \\
\hline 420 & 0.18 & 0.15 & 0.15 & & 0.22 & 0.22 & 0.14 & & 0.18 \\
\hline 320 & 0.40 & 0.65 & 1.02 & 0.32 & 0.40 & 0.64 & 0.14 & & 0.32 \\
\hline 270 & 2.16 & 2.50 & 2.50 & 2.45 & 2.16 & 2.00 & 2.50 & 2.50 & 1.45 \\
\hline 255 & 2.00 & & & & & & & 2.36 & 1.55 \\
\hline 250 & 2.50 & & & & & & & & \\
\hline 245 & 2.24 & & & & & & & & \\
\hline 240 & 2.32 & & & & & & & & \\
\hline 230 & 2.56 & & & & & & & & \\
\hline
\end{tabular}



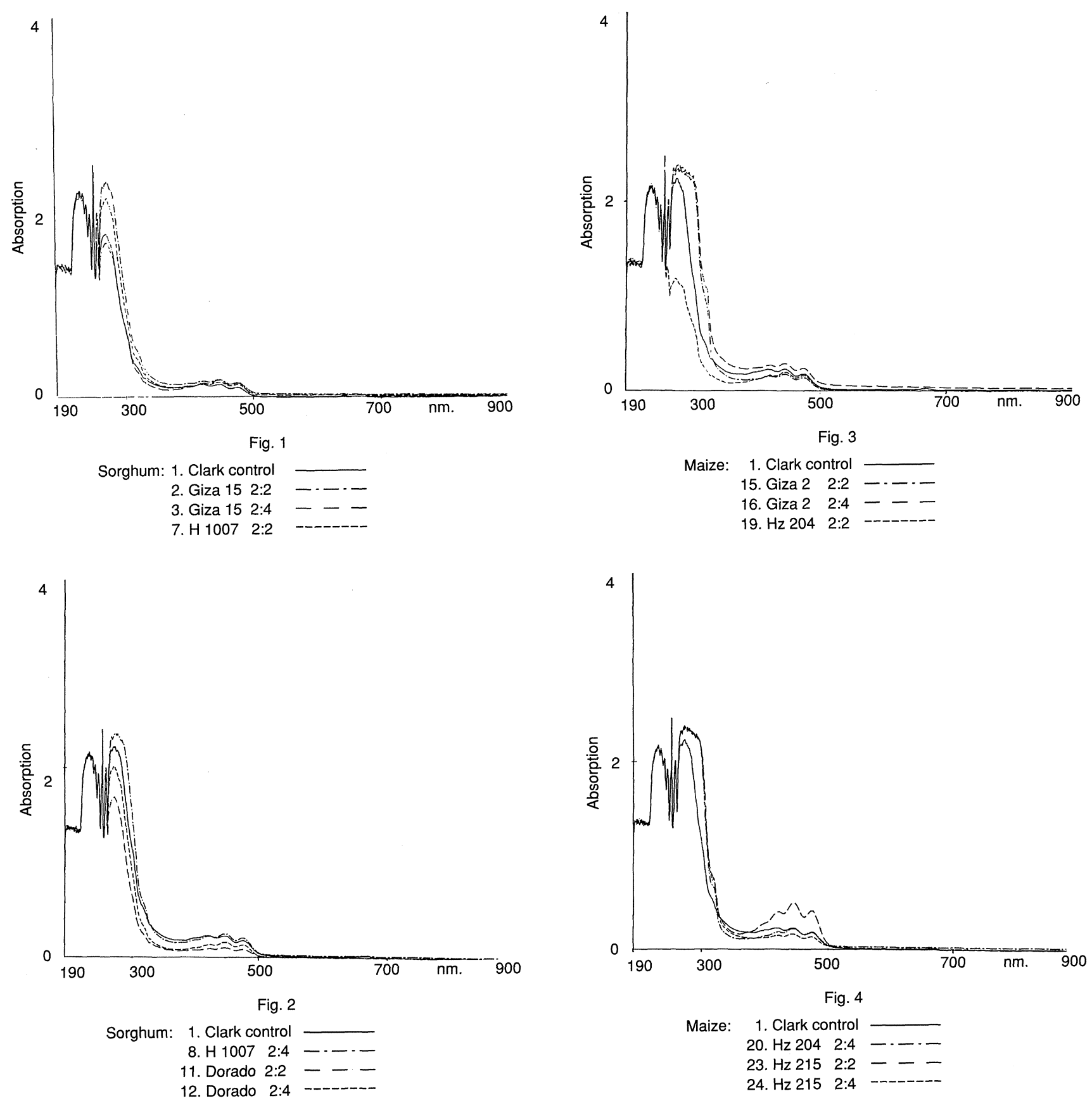

with values between 0.08 and 0.20 for intensification on $\mathrm{H}$ 1007 2:4 and Giza 15 2:4 sorghum varieties, while for the control the minima bands were at 475 and $420 \mathrm{~nm}$ with a value of 0.08 for both the mentioned bands.

Results presented in table VI and figures 8, 9 and 10 it is clear that the oils of Crowmord soybean seeds variety cultivated intensifically on maize varieties had maxima bands at $270 \mathrm{~nm}$ which measured 2.50 for both Giza 2; 2:2 and 2:4, $\mathrm{Hz} 215$ 2:4 and $\mathrm{Hz} 310$ 2:2 but for $\mathrm{Hz} 310,2: 4$ measured 1.55 at $255 \mathrm{~nm}$, while the control Crowmord that was cultivated alone the maxima bands were at 270 and 255 with values 2.16 and 2.00. The minima bands for the oils of Crowmord soybean variety cultivated intensifically on

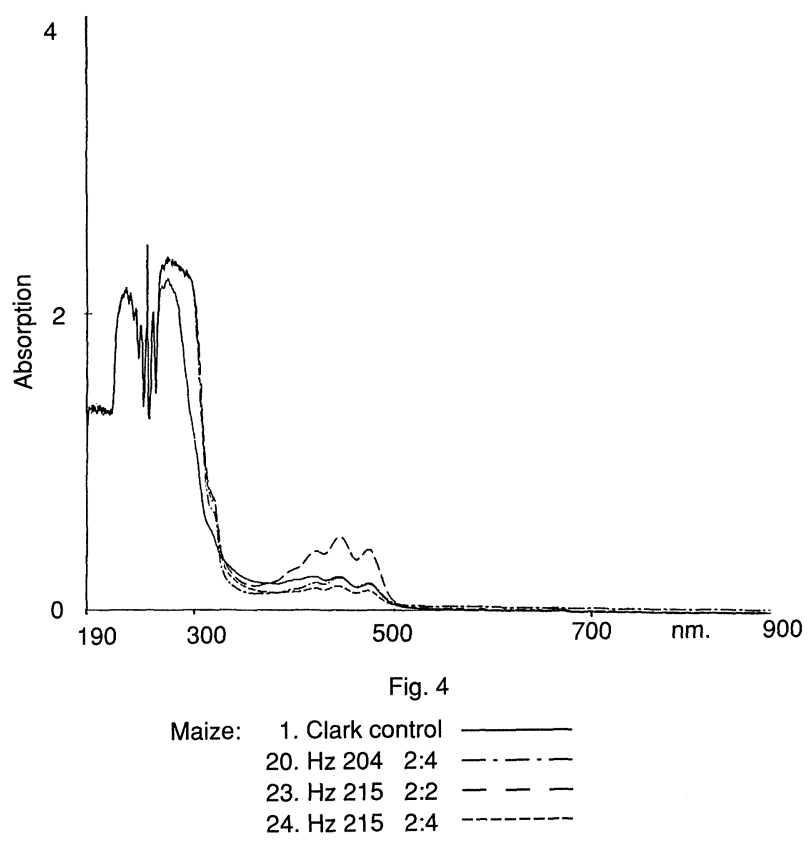

maize varieties were at 475 and $420 \mathrm{~nm}$ ranged between 0.08 for $\mathrm{Hz} 204$ 2:2 and 0.18 for $\mathrm{Hz} 310$ 2:4 and 0.22 for both of $\mathrm{Hz} 2042: 4$ and $\mathrm{Hz} 215$ 2:2, while for the control Crowmord the minima were at 475 and $420 \mathrm{~nm}$ with a measure of 0.18 for both the bands.

The differences in the parameters obtained in this study in the regions $255-475 \mathrm{~nm}$ may be as the results of Gillam and Stern (1957) \& Selverstein and Bassler (1967), that the cromophor groups responsible for absorption at 265-300 $\mathrm{nm}$ regions were carbonyl groups of triglycerides esters and also due to the carotenoid compounds that are responsible for the absorption at $400-500 \mathrm{~nm}$ as the statement of Isler et al. (1956) \& Burkhardt (1968). 


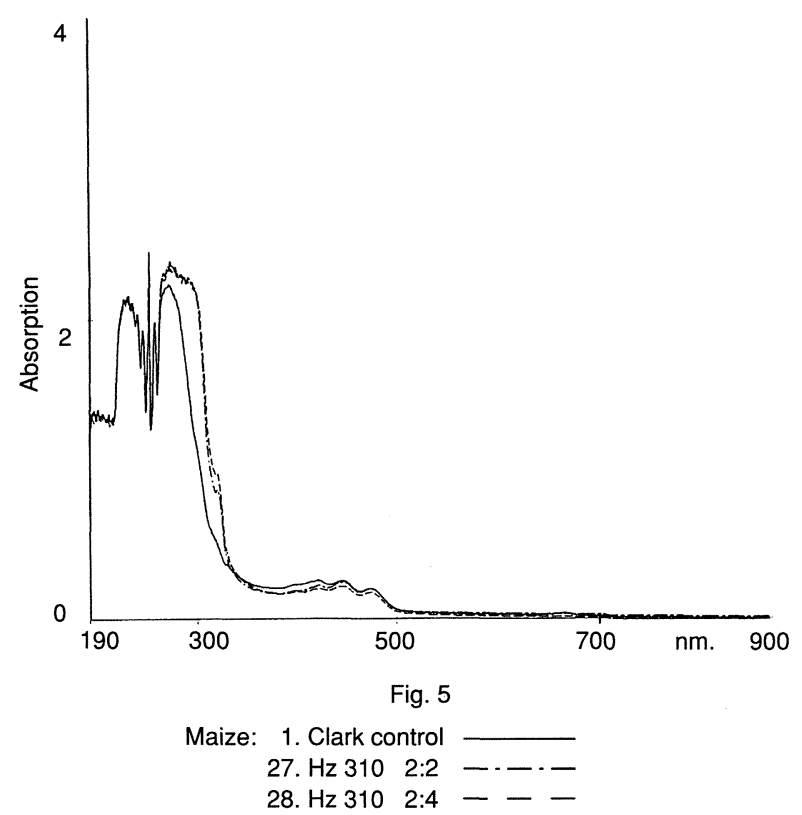

It could be concluded that the intensification of Clark and Crowmord soybean varieties on some sorghum and maize varieties affects the physical properties of the oils extracted of the seeds of the yielded soybean produced from cultivation intensifically on sorghum and maize varieties. The results tabulated in this work were deduced from the regions of differences of U.V. spectra parameters where the highest measures were at band $270 \mathrm{~nm}$ that were 2.50 for soybean oils intensificated on Giza 15 sorghum variety intensity $2: 4$ [2 rows soybean:4 rows sorghum] and Giza 2, $\mathrm{Hz} 215$ and $\mathrm{Hz} 310$ maize varieties intensity $2: 2,2: 4,2: 4$ and $2: 2$ respectively.

From the results the authors could extrude the final conclusion that intensification Clark soybean variety on maize

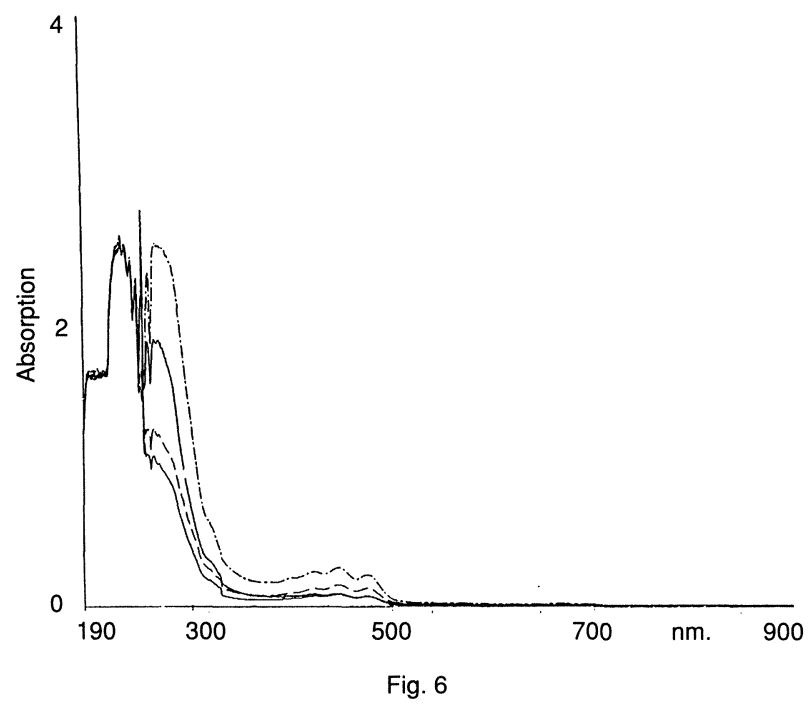

Sorghum: 4. Crowmord control

$$
\begin{aligned}
& \text { 5. Giza } 15 \text { 2:2 } \\
& \text { 6. Giza } 15 \text { 2:4 } \\
& \text { 9. } \mathrm{H} 1007 \quad 2: 2
\end{aligned}
$$

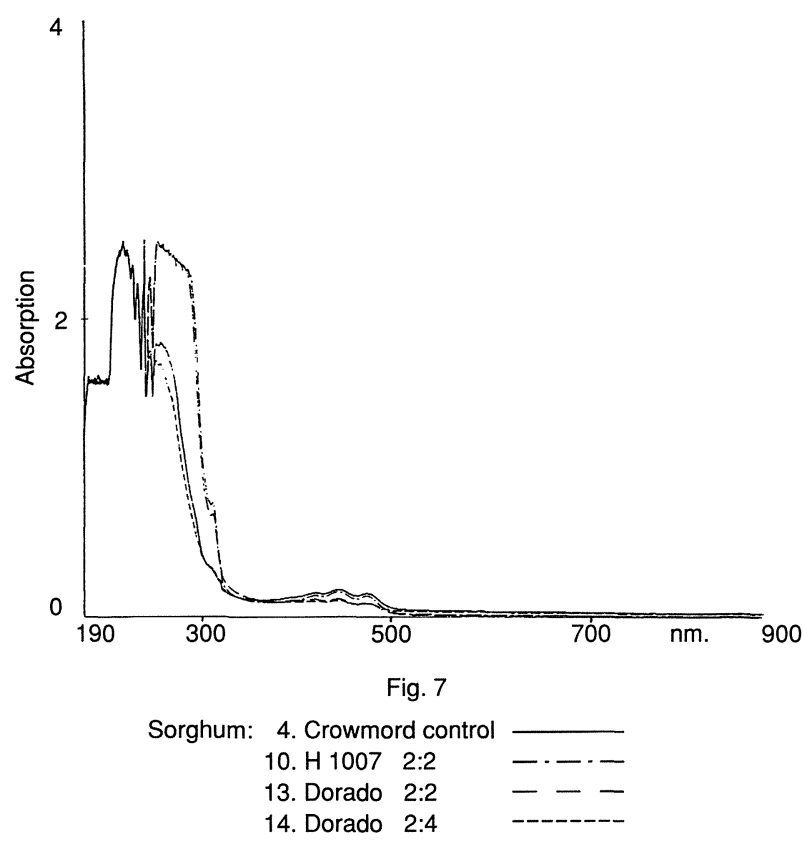

is more effective than on sorghum as the intensification of Crowmord soybean variety on sorghum is more effective than on maize, as the cromophor and carotenoids compounds are in larger quantities in their oils.

Also this interpretation added in clear extrudation that the intensification of Clark soybean variety on $\mathrm{Hz} 310,2: 4$ [2 rows soybean: 4 rows maize] increases cromophor compounds and on $\mathrm{Hz} 215,2: 2$ [2 rows soybean:2 rows maize] increases carotenoids in Crowmord soybean oils. As well as the intensification of Crowmord soybean variety on Dorado sorghum variety increases the carotenoids in its oils.

The increase in cromophor groups is the increase of car-

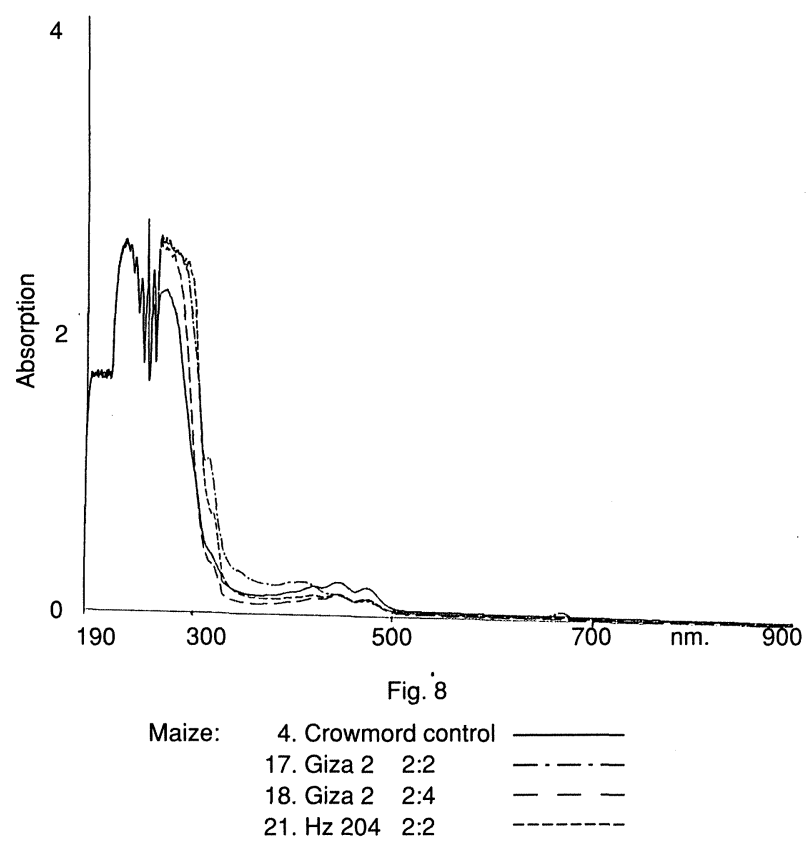




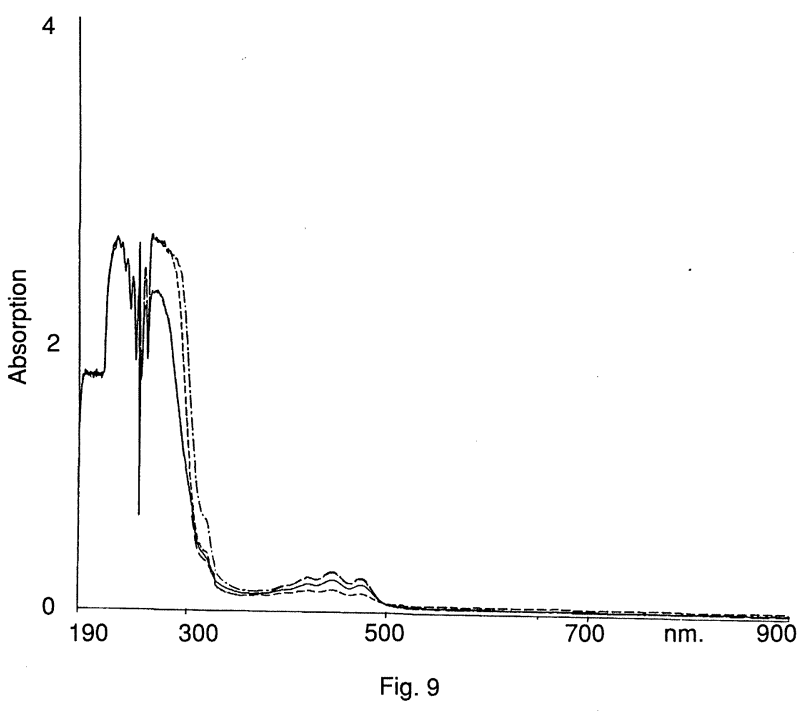

Maize: 4. Crowmord control

$\begin{array}{lll}\text { 22. Hz 204 } & 2: 4 & -\cdot-\cdot- \\ \text { 25. Hz 215 } & 2: 2 & - \\ \text { 26. Hz 215 } & 2: 4 & -\end{array}$

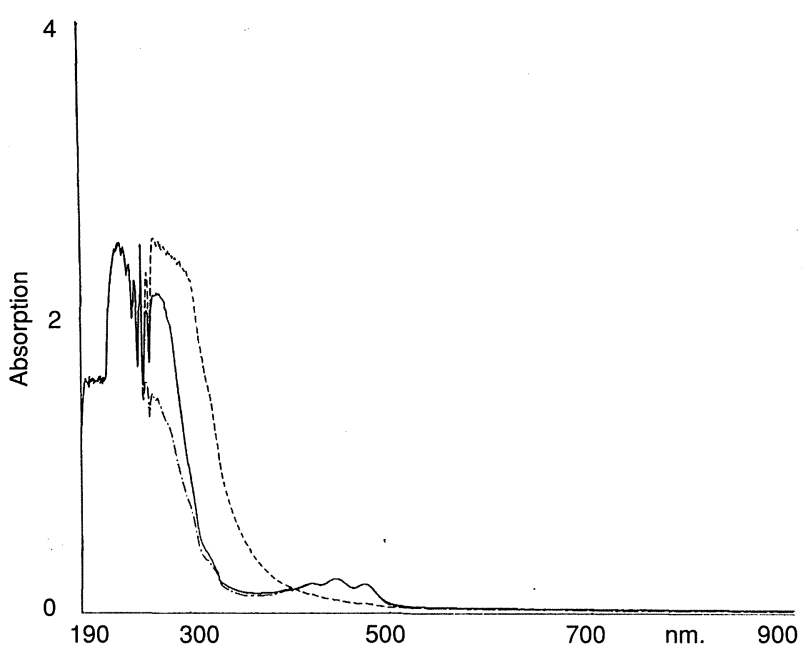

Fig. 10

Maize: 4. Crowmord contro
29. $\mathrm{Hz} 310$ 2:2
30. $\mathrm{Hz} 310 \quad 2: 4$

bonyl groups of triglycerides esters means esterification of the three hydroxyl groups of glycerin to the completeness of soybean seed ripening, as the increase of carotenoids means the increase of B-carotene one of carotenoid compounds and the provitamin $A$ that is essential for the eyes.

\section{REFERENCES}

A.O.A.C. (1980).- «Oficial methods of analysis».-The Association Washington. D.C

Burkhardt, H.J. (1968).-«Color problems in oils from experimental safflower varieties».-J. Am. Oil Chemists'Soc. 45, 96-99.

Davidek, J. and Blattna, J. (1962).-«Chromatography of fat-soluble vitamins on thin layers of alumina».-J. Chromatog. 7, 204-210.

Elsakr, A.S. and Fahmy, A.A. (1991).-J. Agric. Sci. Mansoura Univ. 16, 934944.

Guillam, A.E. and Sterm, E.S. (1975).-«Electronic absorption spectroscopy in organic chemistry".-2 $2^{\mathrm{a}}$ Ed.-Arnold, London.

Grau, R. and Mirna, R. (1985).-«Test method for lard».-Fett Wiss. Technol. 60, 357.

Green, J.: Marcinkiewiez, S. and Watt, P.R. (1955).-J.Sci. Food Agric. 6, 274.

Isler, O.; Lindlar, H.; Montavon, M.; Rüeg, R. and Zeller, P. (1956).-«Synthese in der carotinoid-reihe. Synthese von isozeaxanthin».-Helv. Chem. Acta 39, 449-454.

Morris, W.W. and Haenni, E.O. (1962).-J. Sci. Food Agric. 45, 92-98.

Selverstein, R.M. and Bassler, G.C. (1967).-«Spectrometric identification of organic compounds".--2a Ed.-Wiley, N.Y.

Vogel (1978).- «A textbook of practical organic chemistry, revised by the members of school of chemistry".-4a Ed.-ELBS, Longman Group Ltd., London.

Williams, K.A. (1950).-«Oils, fats and fatty acids, their optical examination».$3^{\mathrm{a}}$ Ed.-London, J.A. Churchill Ltd.

Wilson, P.W.; Kodicek, E. and Booth, V.H. (1962).-«Separation of tocopherols by gas-liquid chromatography".-Biochem. J. 84, 524-531.

(Recibido: Septiembre 1992) 